\title{
Regulation of 11ß-hydroxysteroid dehydrogenase type 2 activity in ovine placenta by fetal cortisol
}

\author{
K A Clarke, J W Ward, A J Forhead, D A Giussani \\ and A L Fowden \\ Department of Physiology, University of Cambridge, Cambridge CB2 3EG, UK \\ (Requests for offprints should be addressed to A L Fowden; Email: alf1000@cam.ac.uk)
}

\begin{abstract}
The effect of fetal cortisol on the activity of the type 2 isoform of the enzyme, $11 \beta$-hydroxysteroid dehydrogenase (11 $\beta$-HSD2), was examined in ovine placenta and fetal kidney by measuring tissue $11 \beta-H S D 2$ activity during late gestation when endogenous fetal cortisol levels rise and after exogenous cortisol administration to immature fetuses before the prepartum cortisol surge. Placental $11 \beta-H S D 2$ activity decreased between 128-132 days and term ( $\approx 145$ days of gestation) in association with the normal prepartum increase in fetal plasma cortisol. Raising fetal cortisol levels to prepartum values in the immature fetus at 128-132 days of gestation reduced placental $11 \beta-\mathrm{HSD} 2$ activity to term values. In contrast, $11 \beta-\mathrm{HSD} 2$
\end{abstract}

activity in the fetal renal cortex was unaffected by gestational age or cortisol infusion. When all the data were combined, there was an inverse correlation between the log fetal plasma cortisol level at delivery and placental $11 \beta-H S D 2$ activity, expressed both on a weight-specific basis and per mg placental protein. Fetal cortisol therefore appears to be a physiological regulator of placental, but not renal, $11 \beta-H S D 2$ activity in fetal sheep during late gestation. These findings have important implications, not only for glucocorticoid exposure in utero, but also for the local actions of cortisol within the placental tissues that are involved in initiating parturition in the sheep.

Journal of Endocrinology (2002) 172, 527-534

\section{Introduction}

The enzyme, 11ß-hydroxysteroid dehydrogenase (11 $\beta$ HSD), interconverts the active glucocorticoids, cortisol and corticosterone, to their inactive 11-keto metabolites. In mammals, the enzyme has two isoforms (Krozowski et al. 1999). The type 1 isoform (11 $\beta-H S D 1)$ is bidirectional and can act either as a dehydrogenase (cortisol to cortisone) or as a reductase (cortisone to cortisol) depending on cofactor availability (Yang 1995a, Krozowski et al. 1999). The second isoform, $11 \beta-H S D 2$, is unidirectional and converts cortisol to cortisone in the presence of NAD (Yang 1995a). The 11 $\beta$-HSD1 isoform is found in a number of adult tissues while $11 \beta-\mathrm{HSD} 2$ is present primarily in aldosterone-sensitive tissues, such as the kidney, colon and salivary glands (White et al. 1997, Burton \& Waddell 1999). Studies in several species including the sheep have shown a similar distribution of $11 \beta-H S D$ isoforms in fetal tissues with high $11 \beta$-HSD2 expression in the fetal kidneys (Langlois et al. 1995, Stewart et al. 1995b, Wood \& Srun 1995, Brown et al. 1996).

Gene expression and bioactivity of $11 \beta-$ HSD have also been detected in the placenta of several species, including the sheep, human, baboon, pig, horse, guinea pig, rat and mouse (Baggia et al. 1990, Chavatte et al. 1995, Kim et al. 1995, Stewart et al. 1995a, Brown et al. 1996, Klemcke \& Christenson 1996, Sampath-Kumar et al. 1998, Waddell et al. 1998). Both 11ß-HSD isoforms are expressed in the placenta but, based on cofactor preference, 11 $\beta-H S D 2$ appears to be the predominant placental isoform in most of these species (Yang 1997). By contrast, in ovine placenta, $11 \beta-H S D 1$ appears to be the predominant mRNA transcript although both isoforms appear to be equally active in converting cortisol to cortisone in this tissue (Yang 1995b, Yang et al. 1997, Murotsuki et al. 1998). In primates and rodents, $11 \beta-H S D 2$ has been localized specifically to surfaces within the placenta involved in fetal-maternal exchange (Krozowski et al. 1995, Brown et al. 1996, Pepe et al. 1996). Placental 11ß-HSD2, therefore, acts as a barrier to the transplacental passage of bioactive glucocorticoids and, thereby, limits fetal exposure to the higher glucocorticoid concentrations found in the maternal circulation (Sun et al. 1998b, Burton \& Waddell 1999). This action of placental $11 \beta-H S D$ has an important impact on fetal development because glucocorticoids regulate tissue growth and differentiation in the fetus (Fowden et al. 1998).

In rodents and baboons, placental 11 $\beta-$ HSD expression and activity are influenced by gestational age, nutritional 
Table 1 The number and gestational ages of the fetuses in the different experimental groups used in the study

\begin{tabular}{|c|c|c|c|c|}
\hline \multicolumn{4}{|l|}{ ou } & \multirow[t]{2}{*}{$\begin{array}{l}\text { No. of } \\
\text { fetuses }\end{array}$} \\
\hline & $\begin{array}{l}\text { Subsequent } \\
\text { treatment }\end{array}$ & $\begin{array}{l}\text { At } \\
\text { catheterization }\end{array}$ & $\begin{array}{l}\text { At tissue } \\
\text { collection }\end{array}$ & \\
\hline \multicolumn{5}{|l|}{$\begin{array}{l}\text { Surgical } \\
\text { treatment }\end{array}$} \\
\hline Unoperated & Untreated & - & $140-142$ & 3 \\
\hline \multirow[t]{3}{*}{ Catheterized } & Saline infused & $115-118$ & $128-132$ & 6 \\
\hline & Cortisol infused & $115-118$ & $128-132$ & 8 \\
\hline & Untreated & 127-132 & $140-142$ & 4 \\
\hline
\end{tabular}

state and sex steroid concentrations (Baggia et al. 1990, Langley-Evans et al. 1996, Sun et al. 1998b, Waddell et al. 1998, Bertram et al. 2001). Gestational trends in placental $11 \beta-H S D 2$ gene expression and/or activity have also been observed in sheep, pigs, guinea pigs and humans (Stewart et al. 1995a, Klemcke \& Christenson 1996, Sampath-Kumar et al. 1988, Whorwood et al. 2001). Similarly, there are changes in renal $11 \beta-H S D 2$ expression and activity between mid and late gestation and in response to hypoxaemia, acidosis and undernutrition in the sheep fetus (Langlois et al. 1995, Wood \& Srun 1995, Asano et al. 1997, Whorwood et al. 2001). In sheep and other species, the fetal adrenal output of glucocorticoids increases towards term and in response to adverse intrauterine conditions, such as undernutrition and hypoxaemia (Fowden \& Silver 1995, Challis et al. 1999). Glucocorticoids have been shown to regulate $11 \beta$-HSD1 activity in fetal ovine liver (Yang et al. 1994) but little is known about their effects on $11 \beta$-HSD2 activity in the placenta or other fetal tissues, such as the kidney. Hence, in the present study, $11 \beta-$ HSD 2 activity was measured in ovine placenta and fetal kidney during the period of late gestation when endogenous fetal cortisol levels rise and after exogenous cortisol administration to fetuses before the prepartum cortisol surge.

\section{Materials and Methods}

Animals

A total of 21 Welsh Mountain sheep fetuses of known gestational age were used in this study. All fetuses were alive at delivery. Food but not water was withdrawn from the ewes $(n=18) 18-24 \mathrm{~h}$ before surgery. All procedures were carried out under the Animals (Scientific Procedures) Act 1986.

\section{Surgical procedures}

Under halothane anaesthesia $\left(1.5 \%\right.$ in $\left.\mathrm{O}_{2} / \mathrm{N}_{2} \mathrm{O}\right)$, catheters were inserted into the dorsal aorta and caudal vena cava in
17 of the fetuses using the surgical procedures described previously (Fowden et al. 1996). The numbers and gestational ages of the fetuses at catheterization are shown in Table 1 (term $145 \pm 2$ days). Antibiotic was given to the fetus intravenously at the end of surgery $(100 \mathrm{mg}$ ampicillin; Penbritin, Smith Kline Beecham, Dun Laoghaire, Co Dublin, Ireland) and to the mother intramuscularly on the day of surgery and for 3 days thereafter (1 g procaine benzyl-penicillin; Depocillin, Intervet, Milton Keynes, Bucks, UK).

\section{Experimental procedures}

Arterial blood samples of $2 \mathrm{ml}$ were taken daily during the experimental period to monitor fetal well-being and to determine plasma cortisol concentrations. At least 6 days after catheterization, 14 fetuses were infused intravenously with either cortisol $(n=8 ; 1-3 \mathrm{mg} /$ day in $2.5 \mathrm{ml} 0.9 \%$ (w/v) saline; EF-Cortelan; Glaxo Ltd, Greenford, Middx, UK) or saline $(n=6 ; 2.5 \mathrm{ml} /$ day $0.9 \%(\mathrm{w} / \mathrm{v}))$ for 5 days beginning between 123 and 127 days of gestation. Treatment was continued until tissue collection which occurred at the end of day 5 of infusion. Fetuses treated with cortisol were chosen at random. The dose of cortisol was designed to produce concentrations of plasma cortisol similar to those observed in the immediate prepartum period (Fowden et al. 1996). The four remaining fetuses catheterized late in gestation were sampled daily until delivery at 140-142 days of gestation (Table 1).

\section{Tissue collection}

All operated fetuses, regardless of previous treatment, and four additional unoperated, untreated fetuses were delivered by Caesarean section under sodium pentobarbitone anaesthesia $(20 \mathrm{mg} / \mathrm{ml}$, i.v.); details of the numbers and the ages of the fetuses at delivery are given in Table 1. Blood samples were taken from the fetuses at the time of delivery either through the indwelling catheters immediately before anaesthesia or by venipuncture from the umbilical artery after anaesthesia had been induced. 
After administration of a lethal dose of anaesthetic to the fetus and ewe (200 mg/ $\mathrm{kg}$ sodium pentobarbitone), samples of placenta (two to three placentomes) and fetal kidney were collected and frozen rapidly in liquid nitrogen before storage at $-80{ }^{\circ} \mathrm{C}$. All blood samples were centrifuged immediately at $4{ }^{\circ} \mathrm{C}$ and the plasma was stored at $-20{ }^{\circ} \mathrm{C}$.

\section{Biochemical analyses}

Cortisol Plasma cortisol concentrations were measured by radioimmunoassay validated for ovine plasma (Robinson et al. 1984). The interassay coefficient of variation was $10 \%$ and the minimum detectable quantity of cortisol was $1.5 \mathrm{ng} / \mathrm{ml}$.

Tissue 11ß-HSD2 Tissue $11 \beta-H S D 2$ activity was measured using the method described by Wood \& Srun (1995). Known weights of placenta and renal cortex were homogenized $(0 \cdot 2 \mathrm{~g} / \mathrm{ml})$ in ice-cold Krebs-Henseleit buffer containing sodium bicarbonate $(\mathrm{pH} 7 \cdot 4)$. The homogenate was diluted depending on tissue and treatment before measurement of $11 \beta-H S D 2$ activity using $\mathrm{NAD}$ as the cofactor. Each assay contained tritiated cortisol (45 000 d.p.m., specific activity $58 \mathrm{Ci} / \mathrm{mmol}$; Amersham Pharmacia Biotech, Amersham, Bucks, UK), unlabelled cortisol $(0 \cdot 1 \mu \mathrm{M}$; Sigma, Poole, Dorset, UK) and NAD $(400 \mu \mathrm{M}$; Sigma) in $0.4 \mathrm{ml}$ Krebs-Henseleit buffer $(\mathrm{pH}$ $7 \cdot 4$ ). The mixture of substrate and cofactor was warmed at $37^{\circ} \mathrm{C}$ for $10 \mathrm{~min}$ before $100 \mu \mathrm{l}$ tissue homogenate containing $0.5-1.2 \mathrm{mg}$ protein was added. After incubation for times chosen to give a linear rate of reaction (2$10 \mathrm{~min})$, the reaction was stopped by addition of ice-cold ethyl acetate $(5 \mathrm{ml})$ containing $20 \mu \mathrm{g}$ of both unlabelled cortisol and cortisone (Sigma) as internal carriers for the chromatography. After extraction of the steroids, the extracts were dried under an air stream at $37^{\circ} \mathrm{C}$, redissolved in a small volume $(120 \mu \mathrm{l})$ of absolute ethanol and spotted onto thin-layer chromatography plates (LK5F Silica gel 150Å; Whatman, Clifton, New Jersey, USA). The plates were developed using a mixture of chloroform and methanol $(9: 1, \mathrm{v} / \mathrm{v})$. The bands containing cortisol and cortisone were visualized under UV light and excised into scintillation vials. Liquid scintillation cocktail (Optiphase II, Hisafe; Wallac Oy, Turku, Finland) was added and the resulting counts corrected for quenching.

The conversion of cortisol to cortisone was expressed as the percentage conversion of recovered tritium counts in the cortisone band. Using the specific activity of the cortisol and the percentage conversion to cortisone, the conversion rate of cortisol to cortisone was calculated and expressed as the amount of cortisone ( $\mathrm{pmol}$ ) synthesized per min. The assay was performed in duplicate at each time-point and a minimum of three time-points were used per sample assayed. Blanks which contained no tissue homogenate were included in each assay to allow correc- tion for non-enzymatic oxidation. The protein content of the homogenate was measured using the Lowry assay (Lowry et al. 1951). Using a placental sample, the interassay coefficients of variation for the protein and $11 \beta$ HSD2 assays were $8 \cdot 5 \%$ and $12 \cdot 0 \%$ respectively. Kinetic parameters were calculated for placental tissue by Lineweaver-Burke plot over substrate concentrations of $0 \cdot 03-0 \cdot 3 \mu \mathrm{M}$ cortisol. The apparent $K_{\mathrm{m}}(78-85 \mathrm{nM})$ and maximum velocity of reaction $(11-13 \mathrm{nmol} / \mathrm{min}$ per $\mathrm{mg}$ protein) were similar to the values published previously for $11 \beta-H S D-2$ in ovine placenta during late gestation (Yang 1995b).

\section{Statistical analyses}

Means and S.E.M. have been given throughout and statistical analysis was made using Sigmastat software (SPSS Inc., Chicago, IL, USA). Statistical significance was assessed by one-way ANOVA using Tukey or KruskalWallis post-hoc tests, as appropriate. Correlation coefficients were calculated by linear regression analyses and assessed for significance using Fisher's $t$-test. Probabilities of less than $5 \%$ were considered significant. Since there were no differences between the catheterized and unoperated fetuses at 140-142 days, values from these two groups were combined for all subsequent analyses.

\section{Results}

\section{The effects of gestational age}

At delivery, the arterial concentration of plasma cortisol was significantly higher at 140-142 days than in the saline-infused animals at 128-132 days of gestation (Table 2). Fetal, but not placental weight, was also significantly greater at 140-142 days than earlier in gestation (Table 2). At 140-142 days, 11 $\beta-H S D 2$ activity per gram placenta was significantly lower than the value in the saline-infused fetuses at 128-132 days (Table 3). Since there was no significant change in the placental protein content with increasing gestational age (Table 3), placental $11 \beta-H S D 2$ activity per $\mathrm{mg}$ protein was also significantly less at 140-142 days than in the saline-infused fetuses at 128-132 days of gestation (Table 3 ). In contrast, there was no apparent gestational trend in $11 \beta-H S D 2$ activity in fetal renal cortex either on a weight-specific basis or when expressed per mg protein (Table 3). However, the protein content of the fetal kidney was significantly lower at 140-142 days than in the saline-infused animals at 128-132 days of gestation (Table 3). No significant differences in blood $\mathrm{pH}$ or gas tensions were observed with increasing gestational age (Table 2).

\section{The effects of fetal cortisol infusion}

Cortisol infusion into the immature fetus raised plasma cortisol concentrations to prepartum values. At delivery at 
Table 2 Mean ( \pm S.E.M.) values of plasma cortisol concentrations, blood pH and gas tensions and of fetal and placental wet weight at delivery in saline- and cortisol-infused fetuses at 128-132 days and in untreated fetuses at 140-142 days of gestation. Numbers of animals are shown in parentheses

\begin{tabular}{|c|c|c|c|c|c|c|c|}
\hline & \multirow[b]{2}{*}{ Treatment } & \multirow{2}{*}{$\begin{array}{l}\text { Cortisol } \\
(\mathrm{ng} / \mathrm{ml})\end{array}$} & \multicolumn{2}{|l|}{ Weight (g) } & \multirow{2}{*}{$\begin{array}{l}\text { Blood } \\
\text { pH }\end{array}$} & \multicolumn{2}{|c|}{ Blood gases $(\mathrm{mmHg})$} \\
\hline & & & Fetus & Placenta & & $\mathrm{pO}_{2}$ & $\mathrm{pCO}_{2}$ \\
\hline \multicolumn{8}{|l|}{$\begin{array}{l}\text { Days of } \\
\text { gestation }\end{array}$} \\
\hline \multirow[t]{2}{*}{$128-132$} & Saline infused & $15 \cdot 1 \pm 2 \cdot 2^{a}(6)$ & $2730 \pm 247^{a}(6)$ & $315 \pm 30^{a}(5)$ & $7 \cdot 364 \pm 0 \cdot 014^{a}(5)$ & $18 \cdot 0 \pm 0 \cdot 8^{\mathrm{a}}(5)$ & $51 \cdot 2 \pm 2 \cdot 2^{\mathrm{a}}(5)$ \\
\hline & Cortisol infused & $59 \cdot 2 \pm 6 \cdot 9^{b}(8)$ & $2822 \pm 152^{\mathrm{a}}(8)$ & $318 \pm 21^{\mathrm{a}}(7)$ & $7 \cdot 354 \pm 0 \cdot 012^{\mathrm{a}}(8)$ & $19 \cdot 6 \pm 1 \cdot 0^{\mathrm{a}}(8)$ & $52 \cdot 0 \pm 1 \cdot 7^{\mathrm{a}}(8)$ \\
\hline $140-142$ & Untreated & $83 \cdot 7 \pm 13 \cdot 6^{\mathrm{b}}(7)$ & $3632 \pm 243^{b}(7)$ & $308 \pm 14^{\mathrm{a}}(5)$ & $7 \cdot 340 \pm 0 \cdot 014^{a}(4)$ & $19 \cdot 0 \pm 2 \cdot 0^{\mathrm{a}}(4)$ & $53 \cdot 7 \pm 2 \cdot 2^{\mathrm{a}}(4)$ \\
\hline
\end{tabular}

Values in columns with different superscripts are significantly different from each other $(P<0 \cdot 01 ; A N O V A)$

128-132 days, the mean cortisol concentration in the cortisol-infused fetuses was significantly higher than that in the saline-infused fetuses and was similar to the value seen in the older, untreated fetuses at 140-142 days (Table 2). Cortisol infusion had no effect on the weights of the fetus and placenta or on fetal blood $\mathrm{pH}$ and gas tensions (Table 2). It also had no apparent effect on the protein content of the placenta (Table 3). In contrast, renal protein content in the cortisol-infused fetuses was significantly lower than that in the saline-infused controls at 128-132 days and was similar to the value found in the untreated fetuses at 140-142 days (Table 3).

Cortisol infusion had no significant effect on 11ß-HSD2 activity in either the placenta or kidney when values were expressed on a weight-specific basis (Table 3). However, when the individual differences in protein content were taken into account, placental $11 \beta-H S D 2$ activity per mg protein was significantly lower in the cortisol- than in the saline-infused animals (Table 3). Cortisol infusion reduced placental $11 \beta-\mathrm{HSD} 2$ activity per mg protein to values similar to those seen in the untreated animals at 140-142 days of gestation (Table 3). Activity of $11 \beta-H S D 2$ per mg protein in the fetal renal cortex was unaffected by cortisol infusion (Table 3).

The relationship between placental $11 \beta-H S D 2$ activity and fetal plasma cortisol

Since both groups of fetuses with elevated cortisol levels, whether of exogenous or endogenous origin, had lower placental $11 \beta-H S D 2$ activities per mg placental protein than the group with low plasma cortisol values, the relationship between placental 11ß-HSD2 activity and fetal plasma cortisol was examined further. When the data from all the fetuses were combined, irrespective of treatment or gestational age, there was a significant inverse correlation between log fetal plasma cortisol at delivery and placental $11 \beta-H S D 2$ activity expressed either per gram wet weight (Fig. 1A) or per mg placental protein (Fig. 1B). No significant correlation was observed between fetal plasma cortisol and renal 11 $\beta-H S D 2$ activity expressed either on a weight-specific basis $(r=0 \cdot 157, n=20, P>0 \cdot 05)$ or per mg renal protein $(r=0 \cdot 396, n=20, P>0 \cdot 05)$. There was also no significant correlation between placental $11 \beta-H S D 2$ activity per mg protein and fetal body weight either at 128-132 days $(r=-0 \cdot 340, n=13, P>0 \cdot 05)$ or at 140-142 days $(r=0 \cdot 076, n=7, P>0 \cdot 05)$.

\section{Discussion}

The results of the present study demonstrate that fetal cortisol affects $11 \beta$-HSD2 activity in the placenta but not in the kidney of fetal sheep during late gestation. In common with the human, guinea pig and rat (Stewart et al. 1995a, Sampath-Kumar et al. 1998, Waddell et al. 1998), placental $11 \beta-H S D 2$ activity fell with increasing gestational age in the sheep in association with the endogenous rise in fetal plasma cortisol concentrations towards term. When fetal cortisol levels were raised earlier

Table 3 Mean ( \pm S.E.M.) values of tissue protein content and 11 $\beta$-HSD2 activity in placenta and kidney from saline- and cortisol-infused fetuses at 128-132 days and from untreated fetuses at 140-142 days of gestation. Numbers of animals are shown in parentheses

\begin{tabular}{|c|c|c|c|c|c|c|c|}
\hline & \multirow[b]{2}{*}{ Treatment } & \multicolumn{2}{|c|}{$\begin{array}{l}\text { Protein } \\
\text { (mg/g wet weight) }\end{array}$} & \multicolumn{2}{|c|}{$\begin{array}{l}\text { 11ß-HSD2 activity } \\
\text { (pmol/min per g wet weight) }\end{array}$} & \multicolumn{2}{|c|}{$\begin{array}{l}\text { 11ß-HSD2 activity } \\
(\mathrm{pmol} / \mathrm{min} \text { per mg protein) }\end{array}$} \\
\hline & & Placenta & Kidney & Placenta & Kidney & Placenta & Kidney \\
\hline \multicolumn{8}{|l|}{$\begin{array}{l}\text { Days of } \\
\text { gestation }\end{array}$} \\
\hline $128-132$ & Saline infused & $122 \pm 3^{\mathrm{a}}(5)$ & $220 \pm 7^{\mathrm{a}}(6)$ & $315 \pm 35^{\mathrm{a}}(5)$ & $4993 \pm 542^{\mathrm{a}}(6)$ & $2 \cdot 63 \pm 0 \cdot 36^{a}(5)$ & $22 \cdot 88 \pm 2 \cdot 30^{\mathrm{a}}(6)$ \\
\hline & Cortisol infused & $132 \pm 4^{\mathrm{a}}(8)$ & $177 \pm 4^{b}(7)$ & $224 \pm 19^{\mathrm{ab}}(8)$ & $4636 \pm 534^{a}(7)$ & $1 \cdot 77 \pm 0 \cdot 17^{\mathrm{b}}(8)$ & $26 \cdot 36 \pm 2 \cdot 70^{\mathrm{a}}(7)$ \\
\hline
\end{tabular}

Values in columns with different superscripts are significantly different from each other $(P<0 \cdot 05 ;$ ANOVA). 


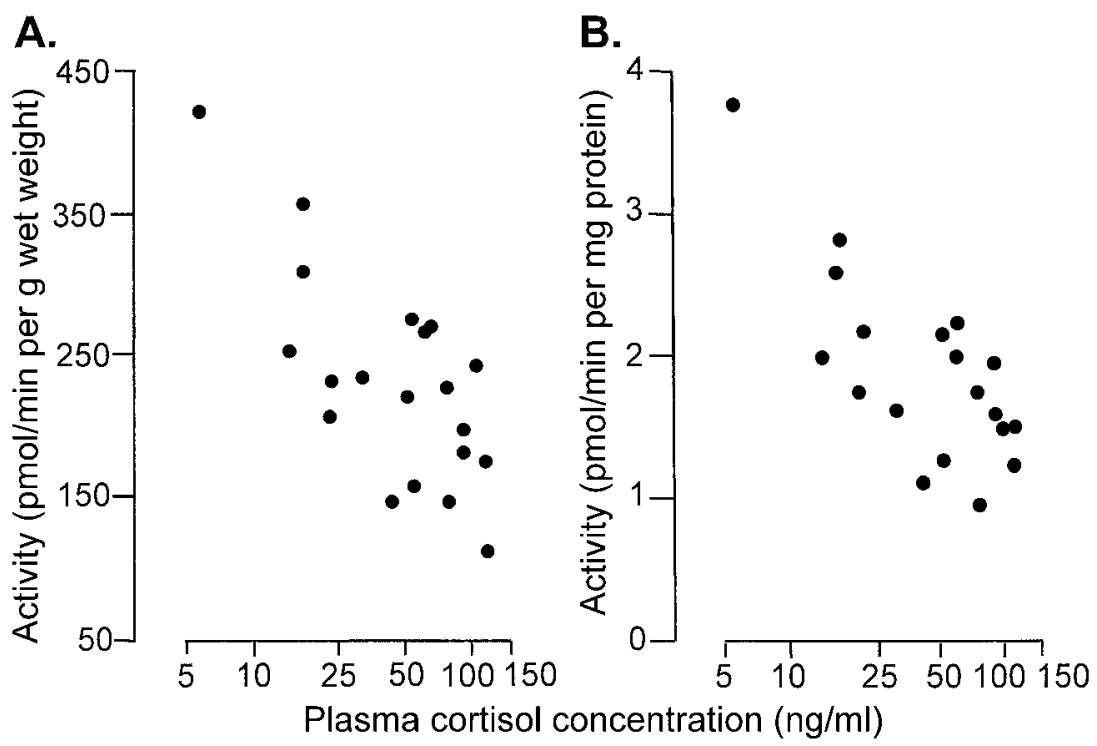

Figure 1 The relationship between placental 11 $\beta$-HSD2 activity expressed (A) on a weight-specific basis $\left(y=-146 \cdot 8 \log _{10} x+474 \cdot 8, r=-0 \cdot 708, n=20, P<0 \cdot 01\right)$ and (B) per $\mathrm{mg}$ placental protein in the individual animals $\left(y=-1 \cdot 37 \log _{10} x+4 \cdot 17, r=-0 \cdot 745, n=20\right.$, $P<0 \cdot 01)$

in gestation by exogenous cortisol administration in the present study, there was a premature fall in placental $11 \beta-H S D 2$ activity per mg protein to values similar to those found in older fetuses. Cortisol, therefore, appears to suppress $11 \beta-H S D 2$ activity in the ovine placenta during late gestation. A similar inhibitory effect of fetal cortisol on $11 \beta-H S D 2$ gene expression has been observed in adrenal glands of fetal sheep close to term (Ross et al. 2000). The inverse correlation observed in the present study between plasma fetal cortisol and placental 11 $\beta-H S D 2$ activity also indicates that fetal cortisol is a physiological regulator of the placental conversion of cortisol to cortisone and suggests that it may increase placental exposure to bioactive glucocorticoids during late gestation. These findings are consistent with previous studies that showed reduced placental $11 \beta-H S D 2$ gene expression in sheep and rats during conditions such as maternal undernutrition which raise glucocorticoid concentrations in utero (Langley-Evans et al. 1996, Bertram et al. 2001, Whorwood et al. 2001). Indeed, cortisol-induced downregulation of placental $11 \beta-H S D 2$ activity could explain, at least in part, the lower transplacental passage of cortisol from ewe to fetus observed during late gestation when fetal cortisol levels are reduced by fetal adrenalectomy (Hennessy et al. 1982).

In contrast to the placenta, cortisol administration had no effect on $11 \beta-H S D 2$ activity in fetal ovine kidneys. There was also no change in renal $11 \beta-H S D 2$ activity during the last 15-20 days of gestation when endogenous cortisol levels rise in the sheep fetus. This finding is consistent with previous observations that showed no

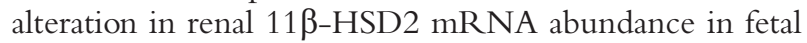

sheep over this period of late gestation (McMillen et al. 2000). However, earlier studies have shown an increase in both renal 11 $\beta-H S D 2$ gene expression and activity between 80-100 days and term (Wood \& Srun 1995, Langlois et al. 1995). Taken together, these observations suggest that renal $11 \beta-H S D 2$ activity may rise during nephrogenesis which occurs throughout mid to late gestation but is complete by about 130 days of gestation in the sheep (Wintour 1997). In late gestation, renal $11 \beta-H S D 2$ gene expression and activity are enhanced by acidosis and reduced by hypoxaemia in fetal sheep, although neither of these factors alter placental 11 $\beta-H S D$ mRNA abundance (Asano et al. 1997, Murotsuki et al. 1998). Reduced renal 11ß-HSD2 expression and activity are also seen in fetal sheep in response to maternal undernutrition during early pregnancy (Whorwood et al. 2001). Activity of $11 \beta-H S D 2$ in fetal ovine kidneys is, therefore, responsive to certain stimuli, although not to cortisol, during late gestation. Since cortisol reduces renal protein content and is known to regulate the activity of other renal enzymes at this stage of gestation (Fowden et al. 1993), its ineffectiveness in altering renal 11ß-HSD2 activity is unlikely to be due to a lack of glucocorticoid receptors (GR) in the fetal kidney. Indeed, GR are present in fetal ovine kidneys from 65 days of gestation and show no change in renal abundance until after birth (Berdusco et al. 1993). The effects of cortisol on 11 $\beta$-HSD2 activity, therefore, appear to be tissue specific in the sheep fetus close to term.

The activities of placental $11 \beta-H S D 2$ per mg protein observed in the present study were within the range of 
values reported previously in sheep during late gestation (Kim et al. 1995, Murotsuki et al. 1998). However, placental $11 \beta-H S D$ activity during late gestation is lower in sheep than in other species, such as the human, pig, horse, baboon, guinea pig and rat (Baggia et al. 1990, Chavatte et al. 1995, Stewart et al. 1995a, Klemcke \& Christenson 1996, Sampath-Kumar et al. 1998, Waddell et al. 1998). These animals have higher maternal glucocorticoid concentrations and greater transplacental glucocorticoid gradients than sheep at a similar stage of gestation (Fowden \& Silver 1995, Fowden et al. 1998). In the present study, the activity of $11 \beta-H S D 2$ per mg protein in the fetal kidneys was four- to fivefold higher than observed in previous studies of fetal sheep at a similar gestational age (Wood \& Srun 1995, Asano et al. 1997, Murotsuki et al. 1998). Selective use of the renal cortex in the present study may account, in part, for these higher activities, as $11 \beta-H S D 2$ has been localized to the distal convoluted tubules and collecting ducts in the cortex of adult human and rodent kidneys (Cole 1995, Krozowski et al. 1995, Roland et al. 1995).

In ovine placenta, the types 1 and $211 \beta$-HSD isoforms appear to be equally active biologically (Yang 1995b, Murotsuki et al. 1998). Since there is no change in either the dehydrogenase or reductase activity of placental $11 \beta-H S D 1$ during late gestation (Yang et al. 1997), the fall in placental $11 \beta-\mathrm{HSD} 2$ activity observed during the last 15-20 days of gestation in the present study represents a 15-20\% decrease in total dehydrogenase activity of the placenta. This fall in placental cortisol to cortisone conversion will enhance the placental effects of rising fetal cortisol concentrations close to term and lead to increased activation of the glucocorticoid-dependent enzymes involved in placental oestrogen synthesis (Sun et al. 1998a, Burton \& Waddell 1999, Patel et al. 1999). The prepartum fall in placental $11 \beta-H S D 2$ activity may, therefore, form part of the endocrine cascade responsible for initiating ovine parturition and contribute to the positive feedback mechanisms that operate during late gestation to ensure delivery of viable lambs at term.

The mechanisms by which cortisol suppresses placental $11 \beta-H S D 2$ activity remain unknown. Cortisol may act directly on the $11 \beta-$ HSD2 gene as glucocorticoid response elements have been identified in the promotor sequence of the human 11ß-HSD gene (Krozowski et al. 1999). Alternatively, cortisol may act indirectly via cortisoldependent transcription factors or other hormones such as oestrogens. Oestrogens are produced by the ovine placenta in response to cortisol and have been shown to suppress $11 \beta-H S D 2$ expression in the human placenta (Sun et al. 1998a, Challis et al. 1999). However, in baboons, oestrogens increase the dehydrogenase activity of placental 11ß-HSD (Baggia et al. 1990). This oestrogen-dependent increase in placental cortisol to cortisone conversion relieves suppression of the fetal hypothalamic-pituitaryadrenal axis and triggers parturition by increasing the adrenal supply of oestrogen precursors to the placenta in the baboon (Pepe \& Albrecht 1995). Although regulation of placental 11 $\beta-H S D$ activity differs between sheep and baboons in late gestation, the net outcome of the regulatory processes is to facilitate the changes in placental hormone synthesis responsible for initiating labour in both species.

The cortisol dependence of placental 11 $\beta-H S D 2$ activity in the ovine placenta also has important implications for fetal development before term. Increases in fetal cortisol levels induced by adverse intrauterine conditions before term may reduce placental $11 \beta-\mathrm{HSD} 2$ activity and, thereby, enhance placental exposure to both fetal and maternal cortisol and increase access of maternal cortisol to fetal tissues. In the placenta, the increased glucocorticoid exposure will alter the production of hormones, such as prostaglandin $\mathrm{E}_{2}$ and placental lactogen, which favour fetal survival during adverse circumstances (Challis et al. 1999, McLaren et al. 2000, Ward et al. 2000). In the fetus, the increased transplacental passage of maternal cortisol may also aid fetal survival by amplifying the glucocorticoidinduced switch from tissue accretion to tissue differentiation which contributes to the fall in fetal growth rate observed during adverse intrauterine conditions, such as undernutrition and hypoxaemia (Fowden et al. 1996, 1998). However, if the reduced placental $11 \beta-H S D 2$ activity persists, even after restoration of normal conditions in utero, fetal development may be compromised by prolonged exposure to maternal glucocorticoids with longterm consequences for postnatal development and the incidence of adult onset degenerative diseases (Barker 2001). Fetal body weight was unrelated to placental $11 \beta-H S D$ activity in the small number of fetuses used in the present study but positive correlations have been observed between placental $11 \beta-$ HSD activity and body weight at delivery in larger cohorts of human infants and rat pups (Benediktsson et al. 1993, Stewart et al. 1995a). The current findings are therefore consistent with the hypothesis that placental $11 \beta-H S D 2$ activity has an important role in the intrauterine programming of adult disease (Seckl et al. 1995, Sun et al. 1998b). However, since cortisol had no effect on renal $11 \beta-H S D 2$ activity in the present study, the postnatal hypertension and reduction in renal $11 \beta-H S D 2$ gene expression associated with adverse intrauterine conditions, such as undernutrition (Seckl et al. 1995, Langley-Evans et al. 1996, Whorwood et al. 2001), are unlikely to be due to cortisol-dependent changes in renal $11 \beta-\mathrm{HSD} 2$ activity sustained in utero.

\section{Acknowledgements}

We would like to thank Paul Hughes for his help with surgery and sampling, Sue Nichols and Vicky Johnson for their care of the animals, Malcolm Bloomfield for his assistance with the biochemical analyses and Nicola 
Allanson and Dee Hughes for their help in preparing the manuscript. We are also indebted to the BBSRC and Tommy's Campaign for their financial support of this work.

\section{References}

Asano H, Shearman K, Darnel A, Richardson BS \& Yang K 1997 Effects of sustained hypoxaemia with 72 hours recovery on $11 \beta$-hydroxysteroid dehydrogenase types 1 and 2 gene expression in near-term fetal sheep. Reproduction, Fertility and Development 9 $755-761$.

Baggia S, Albrecht ED \& Pepe GJ 1990 Regulation of $11 \beta-$ hydroxysteroid dehydrogenase activity in the baboon placenta by estrogen. Endocrinology 126 2742-2748.

Barker DJP 2001 Fetal origins of cardiovascular and lung disease. Lung Biology in Health and Disease 151 1-22.

Benediktsson R, Lindsay RS, Noble J, Seckl JR \& Edwards CRW 1993 Glucocorticoid exposure in utero: new model for adult hypertension. Lancet 341 399-341.

Berdusco ETM, Yang K, Challis JRG \& Hammond GL 1993 Tissue distribution of $\alpha$-proteinase inhibitor messenger ribonucleic acid and its regulation by glucocorticoids in fetal and neonatal sheep. Biology of Reproduction 49 816-821.

Bertram C, Trowen AR, Copin N, Jackson AA \& Whorwood CB 2001 The maternal diet during pregnancy programs altered expression of the glucocorticoid receptor and type 2 $11 \beta$-hydroxysteroid dehydrogenase: potential molecular mechanisms underlying the programming of hypertension in utero. Endocrinology 142 2841-2853.

Brown RW, Diaz R, Robson AC, Kotelevtsev YV, Mullins JJ, Kaufman MH \& Seckl JR 1996 The ontogeny of $11 \beta$-hydroxysteroid dehydrogenase type 2 and mineralocorticoid receptor gene expression reveal intricate control of glucocorticoid action in development. Endocrinology 137 794-797.

Burton PJ \& Waddell BJ 1999 Dual function of 11ß-hydroxysteroid dehydrogenase in placenta: modulating placental glucocorticoid passage and local steroid action. Biology of Reproduction 60 234-240.

Challis JRG, Cox DB \& Sloboda DM 1999 Regulation of corticosteroids in the fetus: control of birth and influence in adult disease. Seminars in Neonatology 4 93-97.

Chavatte P, Rossdale PD \& Tait AD 1995 11 $\beta$-Hydroxysteroid dehydrogenase (11 $\beta-H S D)$ in equine placenta. American Association of Equine Practitioners 41 264-265.

Cole TJ 1995 Cloning of the mouse $11 \beta$-hydroxysteroid dehydrogenase type 2 gene: tissue specific expression and localization in distal convoluted tubule and collecting ducts of the kidney. Endocrinology 136 4693-4696.

Fowden AL \& Silver M 1995 Comparative development of the pituitary-adrenal axis in the fetal foal and lamb. Reproduction in Domestic Animals 30 170-177.

Fowden AL, Mijovic J \& Silver M 1993 The effects of cortisol on hepatic and renal gluconeogenic enzyme activities in the sheep fetus during late gestation. Journal of Endocrinology 137 213-222.

Fowden AL, Szemere J, Hughes P, Gilmour RS \& Forhead AJ 1996 The effects of cortisol on the growth rate of the sheep fetus during late gestation. Journal of Endocrinology 151 97-105.

Fowden AL, Li J \& Forhead AJ 1998 Glucocorticoids and the preparation for life after birth: are there long term consequences of the life insurance? Proceedings of the Nutrition Society 57 113-122.

Hennessy DP, Coghlan JP, Hardy KJ, Scoggins BA \& Wintour EM 1982 The origin of cortisol in the blood of fetal sheep. Journal of Endocrinology 95 71-79.

Kim E-K, Wood CE \& Keller-Wood M 1995 Characterization of $11 \beta$-hydroxysteroid dehydrogenase activity in fetal and adult ovine tissues. Reproduction, Fertility and Development 7 377-383.
Klemcke HG \& Christenson RK 1996 Porcine placental 11ßhydroxysteroid dehydrogenase activity. Biology of Reproduction $\mathbf{5 5}$ 217-223.

Krozowski Z, Maguire JA, Stein-Oakley AN, Dowling J, Smith RE \& Andrews RK 1995 Immunohistochemical localization of the $11 \beta$-hydroxysteroid dehydrogenase type II enzyme in human kidney and placenta. Journal of Clinical Endocrinology and Metabolism $802203-2209$.

Krozowski Z, Li KXZ, Koyama K, Smith RE, Obeyesekere VR, Stein-Oakley A, Sasano H, Coulter C \& Sheppard KE 1999 The type 1 and type II 11ß-hydroxysteroid dehydrogenase enzymes. Journal of Steroid Biochemistry and Molecular Biology 69 391-401.

Langley-Evans SC, Phillips GJ, Benediktsson R, Gardner DS, Edwards CRW, Jackson AA \& Seckl JR 1996 Protein intake in pregnancy, placental glucocorticoid metabolism and the programming of hypertension in the rat. Placenta 17 169-172.

Langlois DA, Matthews SG, Yu M \& Yang K 1995 Differential expression of $11 \beta$-hydroxysteroid dehydrogenase 1 and 2 in developing ovine fetal liver and kidney. Journal of Endocrinology 147 405-411.

Lowry OH, Rosenbrough NJ, Farr AL \& Randall RJ 1951 Protein measurements within folin-phenol reagent. Journal of Biological Chemistry 193 267-275.

McLaren WJ, Young IR \& Rice GE 2000 Localisation and temporal changes in prostaglandin $\mathrm{G} / \mathrm{H}$ synthase- 1 and -2 in ovine intrauterine tissues in relation to glucocorticoid-induced and spontaneous labour. Journal of Endocrinology 165 399-410.

McMillen IC, Warnes KE, Adams MB, Robinson JS, Owens JA \& Coulter CL 2000 Impact of restriction of placental and fetal growth on expression of $11 \beta$-hydroxysteroid dehydrogenase type 1 and type 2 messenger ribonucleic acid in the liver, kidney, and adrenal of the sheep fetus. Endocrinology 141 1-5.

Murotsuki J, Gagnon R, Pu X \& Yang K 1998 Chronic hypoxemia selectively down-regulates $11 \beta$-hydroxysteroid dehydrogenase type 2 gene expression in the fetal sheep kidney. Biology of Reproduction 58 234-239.

Patel FA, Sun K \& Challis JRG 1999 Local modulation of $11 \beta$-hydroxysteroid dehydrogenase of glucocorticoid effect on the activity of 15-hydroxyprostaglandin dehydrogenase in human syncytiotrophoblast and placental trophoblast cells. Journal of Clinical Endocrinology and Metabolism 84 395-400.

Pepe GJ \& Albrecht ED 1995 Actions of placental and fetal adrenal steroid hormones in primate pregnancy. Endocrine Reviews 16 608-648.

Pepe GJ, Waddell BJ, Burch MG \& Albrecht ED 1996 Interconversion of cortisol and cortisone in the baboon placenta at midgestation: expression of $11 \beta$-hydroxysteroid dehydrogenase type 1 messenger RNA. Journal of Steroid Biochemistry and Molecular Biology 58 403-410.

Robinson PM, Comline RS, Fowden AL \& Silver M 1984 Adrenal cortex of fetal lamb: changes after hypophysectomy and effects of synacthen on cytoarchitecture and secretory activity. Quarterly Journal of Experimental Physiology 68 15-27.

Roland BL, Krozowski ZS \& Funder JW 1995 Glucocorticoid receptors, mineralocorticoid receptors, $11 \beta$-hydroxysteroid dehydrogenase- 1 and -2 expression in rat brain and kidney: in situ studies. Molecular and Cellular Endocrinology 111 R1-R7.

Ross JT, McMillen IC, Adams MB \& Coulter CL 2000 A premature increase in circulating cortisol suppresses expression of $11 \beta$-hydroxysteroid dehydrogenase type 2 messenger ribonucleic acid in the adrenal of the fetal sheep. Biology of Reproduction $\mathbf{6 2}$ 1297-1302.

Sampath-Kumar R, Matthews SG \& Yang K 1998 $11 \beta$-Hydroxysteroid dehydrogenase type 2 is the predominant isozyme in the guinea pig placenta: decreases in messenger ribonucleic acid and activity at term. Biology of Reproduction 59 1378-1384. 
Seckl JR, Benediktsson R, Lindsay RS \& Brown RW 1995 Placental $11 \beta$-hydroxysteroid dehydrogenase and the programming of hypertension. Journal of Steroid Biochemistry and Molecular Biology 55 447-455.

Stewart PM, Rogerson FM \& Mason JI 1995a Type 2 11 $\beta$ hydroxysteroid dehydrogenase messenger ribonucleic acid and activity in human placenta and fetal membranes: its relationship to birth weight and putative role in fetal adrenal steroidogenesis. Journal of Clinical Endocrinology and Metabolism 80 885-890.

Stewart PN, Whorwood CB \& Mason JI $1995 b$ Type 2 $11 \beta$-hydroxysteroid dehydrogenase in foetal and adult life. Journal of Steroid Biochemistry and Molecular Biology 55 465-471.

Sun K, Yang K \& Challis JRG 1998a Regulation of $11 \beta$-hydroxysteroid dehydrogenase type 2 by progesterone, estrogen, and cyclic adenosine 5-monophosphate pathway in cultured human placental and chorionic trophoblasts. Biology of Reproduction 58 1379-1384.

Sun K, Yang K \& Challis JRG 1998 b Glucocorticoid actions and metabolism in pregnancy: implications for placental function and fetal cardiovascular activity. Placenta 19 353-360.

Waddell BJ, Benediktsson R, Brown RW \& Seckl JR 1998 Tissue-specific messenger ribonucleic acid expression of $11 \beta$-hydroxysteroid dehydrogenase types 1 and 2 and the glucocorticoid receptor within rat placenta suggests exquisite local control of glucocorticoid action. Endocrinology 139 1517-1523.

Ward JW, Wooding FBP \& Fowden AL 2000 Effect of cortisol on binucleate cell numbers in the ovine placenta during late gestation. Journal of Physiology 527 56P.

White PC, Mune T \& Agarwal AK 1997 11ß-Hydroxysteroid dehydrogenase and the syndrome of apparent mineralocorticoid excess. Endocrine Reviews 18 135-156.
Whorwood CB, Firth KM, Budge H \& Symonds ME 2001 Maternal undernutrition during early to midgestation programs tissue specific alterations in the expression of the glucocorticoid receptor, $11 \beta$-hydroxysteroid dehydrogenase isoforms and type 1 angiotensin II receptor in neonatal sheep. Endocrinology 142 2854-2864.

Wintour EM 1997 The renin-angiotensin system and the development of the kidney. Trends in Endocrinology and Metabolism $\mathbf{8}$ 199-207.

Wood CE \& Srun R 1995 Ontogeny of 11 $\beta$-hydroxysteroid dehydrogenase in ovine fetal kidney and lung. Reproduction, Fertility and Development 7 1329-1332.

Yang K 1995a Ovine 11 beta-hydroxysteroid dehydrogenase: from gene to function. Endocrine Research 21 367-377.

Yang K 1995 b Co-expression of two distinct isoforms of $11 \beta$ hydroxysteroid dehydrogenase in the ovine placenta. Journal of Steroid Biochemistry and Molecular Biology 52 337-343.

Yang K 1997 Placental 11 $\beta$-hydroxysteroid dehydrogenase: barrier to maternal glucocorticoids. Reviews of Reproduction 2 129-132.

Yang K, Berdusco ETM \& Challis JRG 1994 Opposite effects of glucocorticoid on hepatic $11 \beta$-hydroxysteroid dehydrogenase mRNA and activity in fetal and adult sheep. Journal of Endocrinology 143 121-126.

Yang K, Langlois DA, Campbell LE, Challis JRG, Krkosek M \& Yu M 1997 Cellular localization and developmental regulation of $11 \beta$-hydroxysteroid dehydrogenase type 1 (11 $\beta$-HSD1) gene expression in the ovine placenta. Placenta 18 503-509.

Received 24 September 2001

Accepted 19 November 2001 